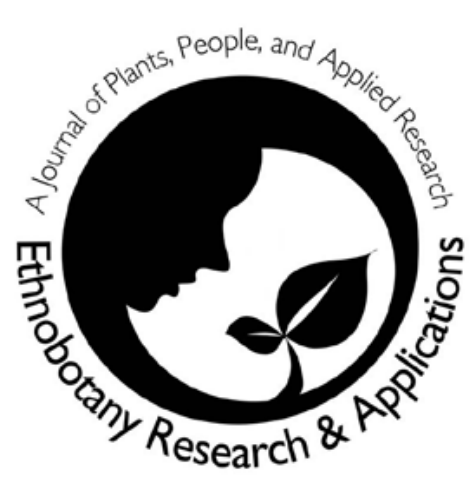

\title{
Ethnobotanical Survey of Woody Plants in Shorobe and Xobe Villages, Northwest Region of Botswana
}

\author{
John Neelo, Keotshephile Kashe, Demel \\ Teketay, and Wellington Masamba
}

\section{Research}

\section{Abstract}

Ethnobotanical investigations were conducted at Xobe and Shorobe Villages in northwestern Botswana to identify woody plants used by the local people. A total of 90 households (35 in Xobe and 55 in Shorobe) were interviewed using a semi-structured questionnaire and personal interviews. A total of 38 woody species representing 16 families and 25 genera were recorded. Of these, 28 species representing 15 families and 22 genera were recorded from Shorobe, and 27 species representing 10 families and 15 genera were recorded from Xobe. The uses of woody plants were grouped into eight categories, namely construction, fuelwood, furniture, medicine, human food, fodder, farm implements, and shade. Several of the species are used for more than one purpose. At both study sites, the use category with the highest proportion of number of woody species and proportion among the use categories was human food. Thirteen of the families were represented by 23 woody species that are used for medicinal purposes, and the most commonly used plant parts were the roots, bark, leaves, and stems. Nine of the 28 woody species (28\%) in Shorobe and nine of the 27 woody species $(33.3 \%)$ in Xobe provide edible parts. Six $(21 \%)$ and eight $(30 \%)$ woody species recorded in Shorobe and Xobe, respectively, are used for construction purposes. Most plants are used as fuelwood for household energy generation. In spite of the scarcity of natural forests in the study areas, the local communities continue to depend on the indigenous woody species in their surroundings for their survival. Virtually all trees identified in the different families are useful in one way or another in the lives of the rural communities, with most of the species serving more than one function. There is, therefore, a need for cultivation, protection, and sustainable manage-
\end{abstract}

ment of these valuable resources for sustaining rural livelihoods in the study sites.

\section{Introduction}

Savanna woodlands are vitally important in providing both ecological (e.g., carbon sequestration, erosion protection, microclimate, wildlife habitats, etc.) and economic services (e.g.. timber, food, fodder, non-wood products, etc.) that sustain local livelihoods and national economies (Chidumayo 1988, Scholes \& Archer 1997). For example, in the southern African region, miombo (savanna) woodlands are economically important for the supply of timber, poles, firewood, charcoal, medicines, food, fiber, and carvings (Chidumayo 1988, Luoga et al. 2000, SADC 1993). They are the major source of energy (fuelwood) for a high percentage of Sub-Saharan African households (Hofstand 1996, Kituyi 2004, Luoga et al. 2002), and serve as sources of food and medicine for many natural resource-dependent households.

\section{Correspondence}

John Neelo, Keotshephile Kashe, Wellington Masamba, Okavango Research Institute, University of Botswana, Private Bag 285, Maun, BOTSWANA.

Demel Teketay, Department of Crop Science and Production, Botswana College of Agriculture, Private Bag 0027, Gaborone, BOTSWANA.

dteketay@yahoo.com, dteketay@bca.bw

Ethnobotany Research \& Applications 14:367-379 (2015)

Published: 12 December 2015 
Wild plants from woodlands and other vegetation types are very important to livelihoods in the subsistence sector, both by meeting a wide range of household needs and through the sale of wood for fuel, thereby generating incomes (Babitseng \& Teketay 2013, Botha et al. 2004, Braedt \& Standa-Gunda 2000, Dovie et al. 2003, Letsela et al. 2003, Neudeck et al. 2012, Teketay et al. 2010). Various studies (e.g., Babitseng \& Teketay 2013, Campbell et al. 2002, Luoga et al. 2000, Motlhanka \& Makhabu 2011, Motlhanka \& Nthoiwa 2012, Neudeck et al. 2012, Shackleton et al. 2002, Teketay et al. 2010) indicated that the majority of rural households make use of non-timber forest products (NTFPs) from their immediate environment, and their harvesting and utilization is a livelihood activity in marginalized communities. Indeed, NTFPs, particularly from savanna woodlands and dry forests, have been identified as important to rural livelihoods as alternative land use options as well as in fulfilling an important safety-net function (Paumgarten 2005). In their natural state, these plants provide spiritual and aesthetic values and ecological services, such as carbon sequestration and water regulation (Shackleton et al. 2007), and, thus, make a significant contribution to local and national production and economic growth (Shackleton 1996).

Ethnobotany, an area of human ecology, defines the interface between people and their plants and offers clues needed for rural development based on sustainable yields of forest products (Gerique 2006). The importance of timber and other tree products from outside forests are attracting increasing attention to help meet growing demands and reduce pressure on natural forests and plantations. Trees growing in open areas seem to have potential to provide options for rural livelihoods and biodiversity conservation. These trees can contribute to poverty mitigation serving as subsistence "safety nets" or low income "gap fillers." In addition to environmental stabilization, trees are useful for industrial, cultural, pharmaceutical, and socio-economic purposes to man, contributing billions of dollars yearly to the world's economy. Estimates have shown that about $90 \%$ of cooking and heating energy comes from trees (WWF/IUCN 1994).

Traditional societies in Africa and elsewhere have always used plants to promote healing, and traditional medicine is still the predominant means of health care in developing countries, e.g., in Botswana (Motlhanka \& Makhabu 2011, Motlhanka \& Nthoiwa 2011, Neudeck et al. 2012), Ethiopia (Teketay et al. 2010), Kenya (Bussmann 2006), Niger (Ayantunde et al. 2009), and Nigeria (Okoli et al. 2007). The Xobe and Shorobe Villages form part of the settlements around the famous Okavango Delta in the northwestern Botswana. In these settlements, which are mainly dominated by subsistence farmers who rely mostly on flood recession (molapo) and dryland farming, woody species are very important and useful (Neelo et al. 2013). The vegetation in this area is becoming so scarce that it is possible for some species to have been wiped out com- pletely. Currently, the vegetation is dominated by grassland with patches of savanna and a few farms scattered around. Trees growing in the open areas of this region contribute to the wide-ranging needs of the rural people. These trees are currently used by the local communities for multiple purposes, such as honey production, food, dye, fiber, fodder, medicines, fuelwood, building materials, fencing, and production of household utensils (Neelo et al. 2013). Some of these trees have support roles for sustainable agriculture, livestock production, and hunting activities while others have cultural, religious, or judicial functions. Most of the activities are major income generators, for example, collection and marketing of the wide range of NTFPs, such as edible fruits, nuts, seeds, and medicines (Leakey \& Newton 1994). The barks of some trees are used to produce ropes, straps, and traditional oil containers while the woods of some are often valued for fuelwood and furniture (Balemie \& Kebebew 2006).

While the knowledge on the usefulness of these plants remains high, poor methods of exploitation, agriculture, and over-exploitation are putting most species under pressure of local extermination (Neelo et al. 2013). Ethnobotanical studies have reported useful plant species in Botswana (Babitseng \& Teketay 2013, Legwaila et al. 2011, Neudeck et al. 2012) and other neighboring countries (Chinemana et al. 1995, Hutchings \& van Staden 1994) and Africa as a whole (Abebe \& Hagos 1991, Holdings \& Njuguna 2001, Teketay et al. 2010), but ethnobotanical surveys on the uses of plants are scanty in Botswana. Most of the available studies conducted focused only on medicinal uses of plants but not the general use of plants, especially in relation to farming. The purpose of this study was, therefore, to document the uses of plants growing in the molapo farming areas of Shorobe and Xobe villages in the northwestern part of Botswana.

\section{Study areas}

The survey was conducted in Xobe and Shorobe villages (Figure 1) located in the Ngamiland District, Northwest Botswana. The two villages fall within the Okavango Delta, part of the wetland system that starts in the highlands of Angola. Communities in these areas practice flood recession farming, which is dependent upon the rainfall at the source averaging $1400 \mathrm{~mm}$ per year, with the Okavango Delta receiving an average of $450-500 \mathrm{~mm}$ per year. The vegetation in Shorobe and Xobe is dominated by mophane (Colophospermum mopane (Benth.) Leonard) and mixed species of Acacia, respectively (DEA 2008, Neelo et al. 2013).

Shorobe Village is located in Ngamiland East Sub-District about $36 \mathrm{~km}$ northeast of Maun. It lies between $19^{\circ} 45^{\prime} 56.71$ 'S and $23^{\circ} 40^{\prime} 10.53$ " $E$ and has a population of 1031 people (CSO 2011). The ethnic groups residing in the study areas include Bayei, Banajwa, Batawana, Basarwa, and Baxereku. 


\section{Neelo et al. - Ethnobotanical Survey of Woody Plants in Shorobe and Xobe Villages, Northwest Region of Botswana}

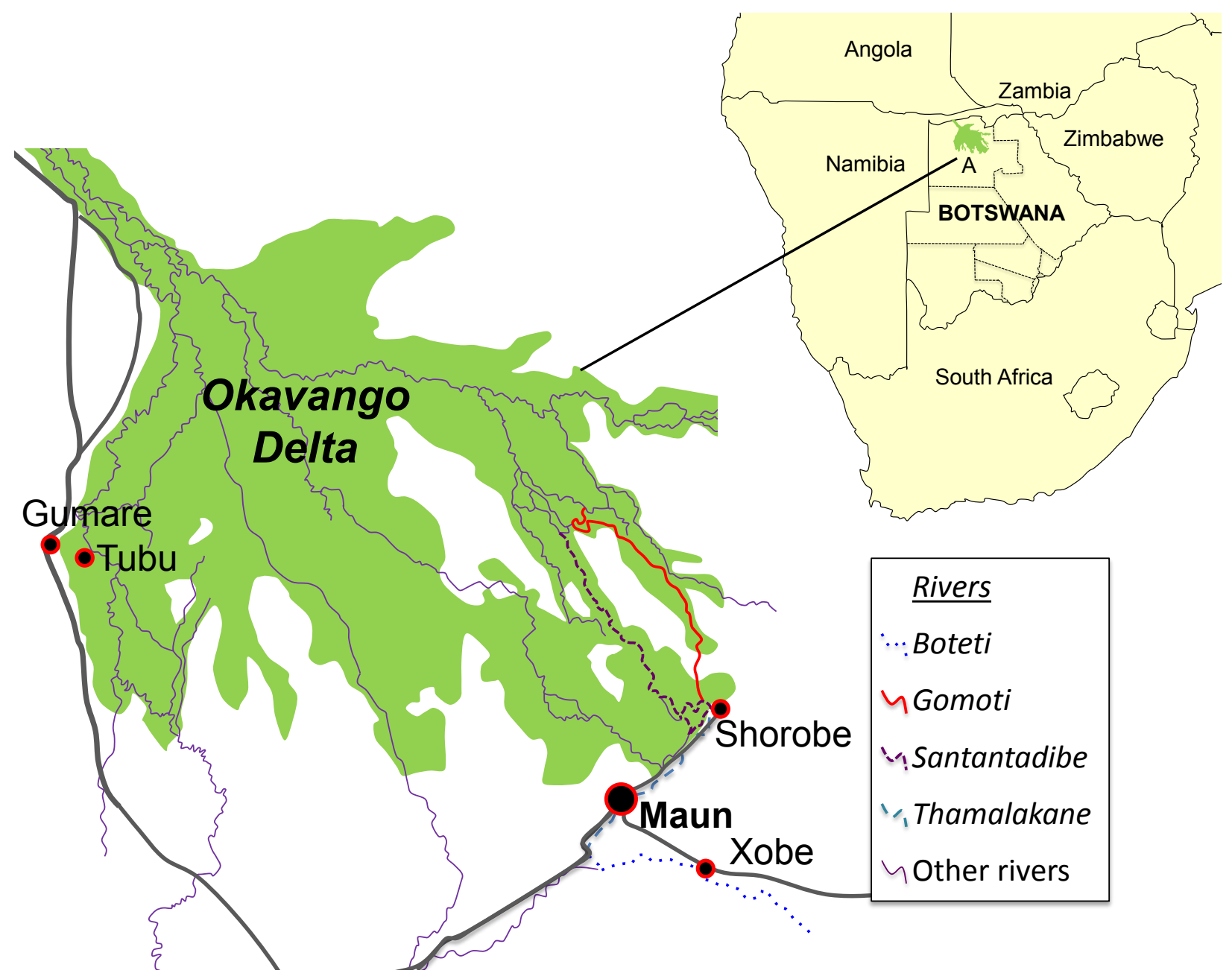

Figure 1. Study sites in Shorobe and Xobe villages, Ngamiland (A), northwest Botswana (Chimbari et al. 2009).

To the northwest of the village, there is an extensive network of molapo fields fed by the Santantadibe and Gomoti rivers and by backflow from the Thamalakane River. Soils in molapo fields are classified as young alluvial soils. Texture varies from clayey ( $35 \%$ to $60 \%$ clay), especially in low-lying areas, through fine loamy ( $18 \%$ to $35 \%$ clay) to coarse loamy ( $<18 \%$ clay) (Chimbari et al. 2009 , Neelo et al. 2013). Flooding of most molapo fields had not occurred for several years until flood waters returned in 2009. When floods occur, molapo fields are cultivated as the flood recedes. The villagers practice both arable and pastoral farming. The local people are also engaged in traditional beer brewing and palm wine making, fishing, and basket weaving. The main crops planted are maize, sorghum, millets, pumpkins, water melons, melons, sweet reeds, beans, and groundnuts (Neelo et al. 2013).

Xobe Village, with a population of 418 people (CSO 2011), is a settlement on the south bank of the Boteti River, about $13 \mathrm{~km}$ east of Maun. The area lies between $20^{\circ} 7^{\prime} 10.26^{\prime \prime} \mathrm{S}$ and $23^{\circ} 27^{\prime} 41.26^{\prime \prime} \mathrm{E}$. The river normally floods in July, but in dry years (e.g., late 1990s) the flood may not reach the settlement. However, the study was conducted during periods when the river was flooding in 2013. Soils in Xobe settlement molapo fields are coarse textured alluvial deposits. Livelihood activities for people in Xobe settlement include rain-fed farming, molapo farming, irrigated vegetable production, and livestock rearing. Molapo farmers cultivate along the river banks as the water flow recedes. Plowing is done using donkeys, though smaller areas may be cultivated with hand hoes. The main crops planted are maize, pumpkins, sweet sorghum, and gourds. Other activities include harvesting of wild plants for sale and fishing (Neelo et al. 2013).

\section{Methods}

Field trips and collection of ethnobotanical data were carried out in August 2013. Data were collected from the two study villages using a semi-structured method adapt- 
ed from Martin (1995). Semi-structured questionnaires were used to interview the local population about their ethnobotanical knowledge of trees. Personal interviews and inquiries were also conducted during field visits. Interviewees were chosen without distinction of gender after seeking the consent from each respondent. People from all age groups, except children below 18 years, were interviewed on their knowledge about the uses of trees in their area. In Shorobe, with a larger population, a total of 55 households were interviewed, whereas, in Xobe because of smaller population only 35 households were interviewed. The number was small but adequate enough to do the analysis (Martin 1995). A random number generator was used to select a sample where a household list of 180 molapo, dryland, and both molapo and dryland farmers was generated. Simple random sampling technique was adopted in the selection of households with a $30 \%$ sampling intensity adopted in Shorobe. In Xobe, because of the smaller population, $100 \%$ of the households were interviewed. Information regarding the different uses of woody plants, parts used, origin, availability, and vernacular names were recorded.

Informants were asked to name the woody plants that they knew and to reveal the uses of the respective species. Informants often accompanied the investigators to the field to clarify and confirm the names of species, and this was possible because the woody plants that informants mentioned were found just around their homes or the nearby bushes. Information was also recorded on the medicinal use of trees, plant parts used, diseases treated, modes of preparation, and administration. The working language was the dialect spoken in this region, Setswana, and the authors faced no language problems. Most plants were easily identified by their common or traditional names. A general vegetation survey had initially been conducted, making plant identification a lot easier. Collected specimens were preserved in the field using standard methods proposed by Martin (1995). Voucher specimens were collected, preserved, and deposited at Peter Smith University of Botswana Herbarium (PSUB). Plant nomenclature follows that of Setshogo (2005).

The floristic similarity of woody plants recorded from the two study sites was determined using Jaccard's Similarity Coefficient (JSC) (Krebs 1989). Data on woody plants, families, uses, origin, availability, vernacular names, and diseases treated were entered into spreadsheets where frequencies and abundance of each species were worked out. Frequency index was calculated for Xobe and Shorobe villages. Frequency index is a mathematical expression of the percentage of frequency of mention for a single botanical species by informants. The following formula was used to calculate frequency index (Madikizela et al. 2012, Mahwasane et al. 2013):

$$
\mathrm{FI}=\mathrm{FC} / \mathrm{N} \times 100
$$

where FC is the number of informants who mentioned the use of the species, and $\mathrm{N}$ is a total number of informants $(\mathrm{N}=35$ in Xobe and 55 in Shorobe). The frequency index was high when there were many informants who mentioned a particular plant and low when there were few reports.

The use-value of each species calculated from the frequency index was, then, used in a Mann-Whitney test (Kirby, 2014) to compare the preferences of use of woody species between the two sites. This was done by ranking all the data from two sites, ignoring which site they belonged to. The lowest value was given a rank of " 1 ," the next lowest getting a rank of "2," and so on. If two or more values were identical, they were then given the average of the ranks that they would have obtained, had they been different from each other. It is very important to note that this procedure "uses up" the ranks of " 1 " and "2," so the next highest value (3) would get a rank of " 3 ." The ranks for the two sites were then summed up and the formulae below used to calculate $\mathrm{U}$ :

$$
\begin{aligned}
& \mathrm{U}_{1}=\mathrm{R}_{1}-\underline{\mathrm{n}}_{1} \frac{\left(\mathrm{n}_{1}+1\right)}{2} \\
& \mathrm{U}_{2}=\mathrm{R}_{2}-\underline{\mathrm{n}}_{2} \frac{\left(\mathrm{n}_{2}+1\right)}{2}
\end{aligned}
$$

where $n_{1}$ is the sample size for Shorobe, $R_{1}$ is the sum of the ranks in site $1, n_{2}$ is the sample size for site 1 , and $R_{2}$ is the sum of the ranks in Xobe.

A Mann-Whitney $U$ test significance table was consulted, comparing the smaller value of $U_{1}$ and $U_{2}$ with the critical value. If the obtained value of $U$ is smaller than the critical value, then the null hypothesis (no difference in values of the two sites) is supported (i.e., the sum of ranks for Shorobe is not different from the sum of ranks of Xobe).

\section{Results}

\section{Floristic composition and similarity}

A total of 38 useful woody species, representing 16 families and 25 genera, were recorded from the two study sites (Table 1). The two study sites shared nine families $(\mathrm{JSC}=0.56)$ and 12 genera $(\mathrm{JSC}=0.48)$. The families recorded from only Shorobe and Xobe were six and one, respectively. Similarly, the genera recorded from only Shorobe and Xobe were 10 and three, respectively. The six plant families with the highest number of species were Fabaceae (31.6\%), Combretaceae (15.8\%), Capparaceae $(7.9 \%)$, Malvaceae $(7.9 \%)$, Ebenaceae $(5.3 \%)$, and Rhamnaceae (5.3\%). All other families were represented by only one species each. The two study sites shared 17 species in common (JSC $=0.45$ ) while 11 and 10 species were recorded only in Shorobe and Xobe, respectively. The six genera with the highest number of species at both 


\section{Neelo et al. - Ethnobotanical Survey of Woody Plants in Shorobe and Xobe Villages, Northwest Region of Botswana}

Table 1. Ethnobotanical information on woody plants in Shorobe and Xobe villages, northwest Botswana. ${ }^{*} \mathrm{CO}=$ construction, $\mathrm{FI}=$ farm implements, $\mathrm{FO}=$ fodder, $\mathrm{FW}=$ fuelwood, $\mathrm{FU}=$ furniture, $\mathrm{HF}=$ human food, $\mathrm{ME}=$ medicine, and $\mathrm{SH}=$ shade.

\begin{tabular}{|c|c|c|c|c|}
\hline \multirow{2}{*}{ Species } & \multirow{2}{*}{ Family } & \multirow{2}{*}{ Local name } & \multicolumn{2}{|c|}{ Uses* } \\
\hline & & & Shorobe & Xobe \\
\hline Acacia erioloba E.Mey. & Fabaceae & Mogotho & $\mathrm{CO}, \mathrm{FU}, \mathrm{SH}$ & $\begin{array}{l}\mathrm{CO}, \mathrm{FI}, \mathrm{FO}, \mathrm{FU} \\
\mathrm{ME}\end{array}$ \\
\hline Acacia erubescens Oliv. & Fabaceae & Moloto & - & $\mathrm{CO}, \mathrm{FW}, \mathrm{HF}$ \\
\hline Acacia hebeclada DC. & Fabaceae & Setshi & $\mathrm{FO}, \mathrm{ME}$ & $\mathrm{ME}$ \\
\hline Acacia luederitzii Engl. & Fabaceae & Mokgwelekgwele & - & FW \& ME \\
\hline Acacia mellifera (M.Vahl) Benth. & Fabaceae & Mongana & - & $\mathrm{CO}, \mathrm{FW}, \mathrm{FU}, \mathrm{ME}$ \\
\hline Acacia tortilis (Forssk.) Hayne & Fabaceae & Mosu & $\mathrm{CO}, \mathrm{FW}, \mathrm{SH}$ & $\mathrm{CO}, \mathrm{FW}$ \\
\hline Albizia anthelmintica Brongn. & Fabaceae & Monoga & ME & $\mathrm{CO}, \mathrm{FW}, \mathrm{SH}$ \\
\hline $\begin{array}{l}\text { Berchemia discolor (Klotzsch) } \\
\text { Hemsl. }\end{array}$ & Rhamnaceae & Motsentsela & $\mathrm{HF}$ & HF, ME \\
\hline $\begin{array}{l}\text { Boscia albitrunca (Burch.) Gilg \& } \\
\text { Benedict }\end{array}$ & Capparaceae & Motopi & $\mathrm{FO}, \mathrm{HF}, \mathrm{ME}, \mathrm{SH}$ & $\mathrm{FO}, \mathrm{HF}, \mathrm{ME}, \mathrm{SH}$ \\
\hline Boscia foetida Schinz & Capparaceae & Mopipi & - & FU \\
\hline Cadaba aphylla (Thunb.) Wild & Capparaceae & Monnamontsho & $\mathrm{ME}$ & - \\
\hline $\begin{array}{l}\text { Carissa bispinosa (L.) Desf. ex } \\
\text { Brenan }\end{array}$ & Apocynaceae & Thaba-di-lebanya & ME & - \\
\hline $\begin{array}{l}\text { Colophospermum mopane } \\
\text { (Benth.) Leonard }\end{array}$ & Fabaceae & Mophane & $\begin{array}{l}\mathrm{CO}, \mathrm{FW}, \mathrm{FU}, \mathrm{ME}, \\
\mathrm{SH}\end{array}$ & FU \\
\hline Combretum collinum Fresen. & Combretaceae & Modubana & $\mathrm{FO}$ & - \\
\hline Combretum hereroense Schinz & Combretaceae & Mokabi & FU & $\mathrm{FI}, \mathrm{FU}$ \\
\hline $\begin{array}{l}\text { Combretum mossambicense } \\
\text { (Klotzsch) Engl. }\end{array}$ & Combretaceae & Motsoketsane & - & $\mathrm{FO}$ \\
\hline Combretum imberbe Wawra & Combretaceae & Motswere & $\mathrm{CO}, \mathrm{FW}, \mathrm{FU}$ & $\mathrm{CO}, \mathrm{FW}, \mathrm{ME}$ \\
\hline Croton megalobotrys Müll.Arg. & Euphorbiaceae & Motsebe & $\mathrm{CO}, \mathrm{ME}, \mathrm{SH}$ & $\mathrm{CO}, \mathrm{ME}, \mathrm{SH}$ \\
\hline $\begin{array}{l}\text { Dichrostachys cinerea (L.) Wight } \\
\text { \& Arn. }\end{array}$ & Fabaceae & Moselesele & - & FW \\
\hline $\begin{array}{l}\text { Diospyros mespiliformis Hochst. } \\
\text { ex A.DC. }\end{array}$ & Ebenaceae & Mokutshumo & FU, HF & - \\
\hline Erythrina lysistemon Hutch. & Fabaceae & Mophethe & $\mathrm{ME}$ & - \\
\hline Euclea undulata Thunb. & Ebenaceae & Motlhakola & ME & - \\
\hline Garcinia livingstonei T.Anderson & Clusiaceae & Motsaudi & $\mathrm{HF}$ & $\mathrm{HF}$ \\
\hline Grewia damine Gaertn. & Malvaceae & Mogwana & $\mathrm{FO}, \mathrm{HF}$ & FO, FU, HF \\
\hline Grewia flava DC. & Malvaceae & Moretwa & $\mathrm{FO}, \mathrm{HF}, \mathrm{ME}$ & $\mathrm{HF}$ \\
\hline Grewia retinervis Burret & Malvaceae & Mokgomphatha & - & $\mathrm{FO}, \mathrm{HF}$ \\
\hline $\begin{array}{l}\text { Hyphaene petersiana Klotzsch } \\
\text { ex Mart. }\end{array}$ & Arecaceae & Mokolwane & $\mathrm{HF}, \mathrm{ME}$ & - \\
\hline Kigelia africana (Lam.) Benth. & Bignoniaceae & Moporota & $\mathrm{SH}$ & - \\
\hline Mimusops zeyheri Sond. & Sapotaceae & Mmupudu & - & $\mathrm{HF}$ \\
\hline $\begin{array}{l}\text { Pavetta schumanniana F.Hoffm. } \\
\text { ex K.Schum. }\end{array}$ & Rubiaceae & Legonyana & ME & ME \\
\hline $\begin{array}{l}\text { Philenoptera nelsii (Schinz) } \\
\text { Schrire }\end{array}$ & Fabaceae & Mohatha & - & $\mathrm{FU}, \mathrm{ME}, \mathrm{SH}$ \\
\hline $\begin{array}{l}\text { Philenoptera violacea (Klotzsch) } \\
\text { Schrire }\end{array}$ & Fabaceae & Mopororo & - & $\mathrm{SH}$ \\
\hline $\begin{array}{l}\text { Sclerocarya birrea (A.Rich.) } \\
\text { Hochst. }\end{array}$ & Anacardiaceae & Morula & $\mathrm{HF}, \mathrm{ME}, \mathrm{SH}$ & - \\
\hline
\end{tabular}




\begin{tabular}{|c|c|c|c|c|}
\hline \multirow{2}{*}{ Species } & \multirow{2}{*}{ Family } & \multirow{2}{*}{ Local name } & \multicolumn{2}{|c|}{ Uses* } \\
\hline & & & Shorobe & Xobe \\
\hline $\begin{array}{l}\text { Securidaca longipedunculata } \\
\text { Fresen. }\end{array}$ & Polygalaceae & Mmaba & ME & - \\
\hline $\begin{array}{l}\text { Terminalia prunioides } \\
\text { M.A.Lawson }\end{array}$ & Combretaceae & Motsiara & $\mathrm{CO}, \mathrm{SH}$ & $\mathrm{CO}, \mathrm{FW}, \mathrm{ME}, \mathrm{SH}$ \\
\hline Terminalia sericea Burch. ex DC. & Combretaceae & Mogonono & FU, ME & FU \\
\hline Ximenia americana L. & Olacaceae & Moretologa & $\mathrm{FO}, \mathrm{HF}, \mathrm{ME}$ & $\mathrm{FO}, \mathrm{HF}$ \\
\hline Ziziphus mucronata Willd. & Rhamnaceae & Mokgalo & FO & - \\
\hline
\end{tabular}

sites were Acacia (15.8\%), Combretum (10.5\%), Grewia (7.9\%), Boscia (5.3\%), Philenoptera (5.3\%), and Terminalia $(4.3 \%)$ (Table 1). All other genera were represented by only one species each.

In Shorobe, a total of 28 useful plants, representing 15 families and 22 genera, were recorded (Table 1). The six plant families with the highest number of species were Fabaceae (21\%), Combretaceae (14.3\%), Capparaceae $(7 \%)$, Ebenaceae $(7 \%)$, Rhamnaceae $(7 \%)$, and Malvaceae $(7 \%)$. All other families were represented by only one species each. The four genera with the highest number of species were Acacia (10.7\%), Combretum (10.7\%), Grewia (7.2\%), and Terminalia (7.2\%). All other genera were represented by only one species each.

In Xobe, a total of 27 useful plants, representing 10 families and 15 genera, were recorded (Table 1). The four plant families with the highest number of species were Fabaceae (40.7\%), Combretaceae (18.5\%), Malvaceae (11\%), and Capparaceae $(7.4 \%)$. All other families were represented by only one species each. The six genera with the highest number of species were Acacia (22.2\%), Combretum (11\%), Grewia (11\%), Boscia (7.4\%), Philenoptera $(7.4 \%)$, and Terminalia $(7.4 \%)$. All other genera were represented by only one species each.

\section{Uses of woody plants}

The uses of woody plants by the local communities in the study sites were grouped into eight categories, namely construction, fuelwood, furniture, medicine, human food, fodder, farm implements, and shade (Table 1 \& Figure 1). Several of the species are used for more than one purpose. Colophospermum mopane and Acacia erioloba E.Mey. are used for five different purposes each in Shorobe and Xobe. Similarly Boscia albitrunca (Burch.) Gilg \& Benedict in both Shorobe and Xobe as well as Acacia mellifera (M.Vahl) Benth. and Terminalia prunioides M.A.Lawson are used for four different purposes each. Those woody species which have three different uses are $A$. erioloba, Combretum imberbe Wawra, Croton megalobotrys Müll. Arg., and Ximenia americana L. in Shorobe, and Acacia erubescens Oliv., Albizia anthelmintica Brongn., C. imberbe, C. megalobotrys, Grewia damine Gaertn., and Philenoptera nelsii (Schinz) Schrire in Xobe (Table 1).

The use category with the highest proportion of woody species (Table 1 \& Figure 2) and proportion among the use categories (Table 1 \& Figure 3 ) was human food followed by shade, fodder, construction, and medicine in Shorobe Village and construction, furniture, and medicine in Xobe Village. Fuelwood and farm implements exhibited

\section{A) Shorobe}

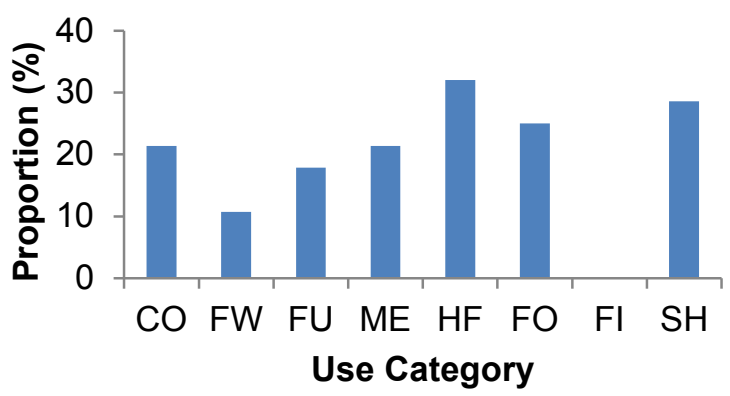

B) Xobe

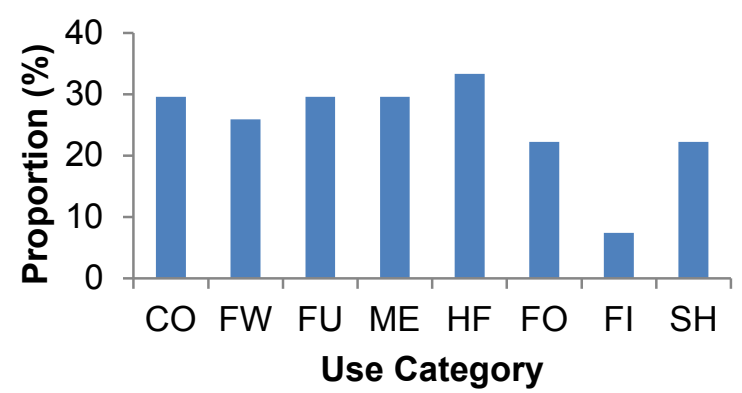

Figure 2. Proportions of woody species in relation to their uses in (A) Shorobe and (B) Xobe villages, northwest Botswana. $\mathrm{CO}=$ construction, $\mathrm{FI}=$ farm implements, $\mathrm{FO}=$ fodder, $\mathrm{FW}=$ fuelwood, $\mathrm{FU}=$ furniture, $\mathrm{HF}=$ human food, ME $=$ medicine , and $\mathrm{SH}=$ shade. 


\section{Neelo et al. - Ethnobotanical Survey of Woody Plants in Shorobe and Xobe Villages, Northwest Region of Botswana}

A) Shorobe

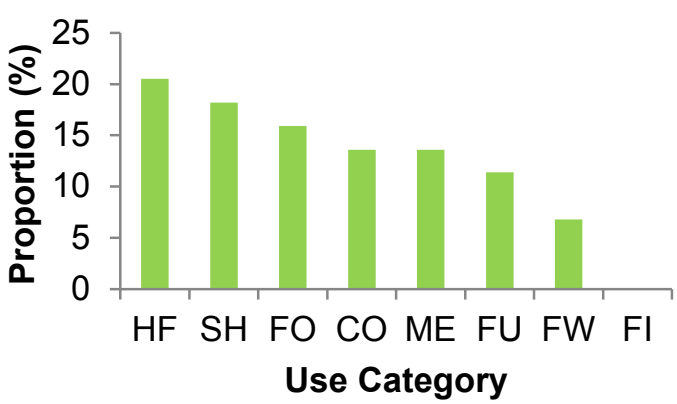

B) Xobe

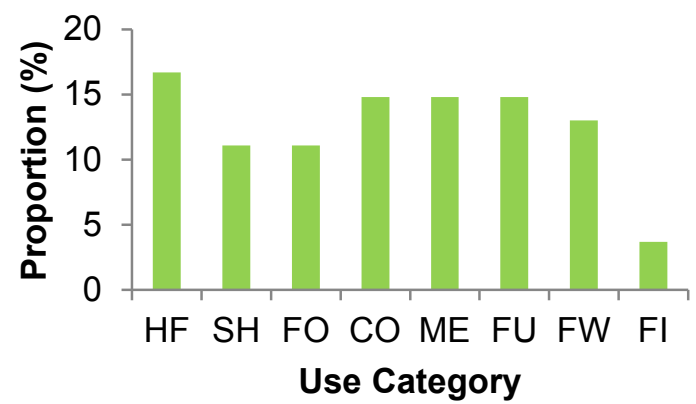

Figure 3. Proportion of categories of use of woody species in (A) Shorobe and (B) Xobe villages, northwest Botswana. $\mathrm{CO}=$ Construction, $\mathrm{FI}=$ farm implements, $\mathrm{FO}=$ fodder, FW = fuelwood, FU = furniture, $\mathrm{HF}=$ human food, ME = medicine, and $\mathrm{SH}=$ shade.

\section{A) Shorobe}

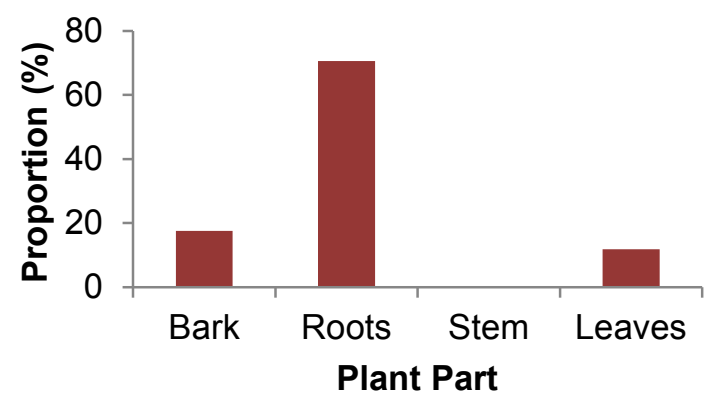

\section{B) Xobe}

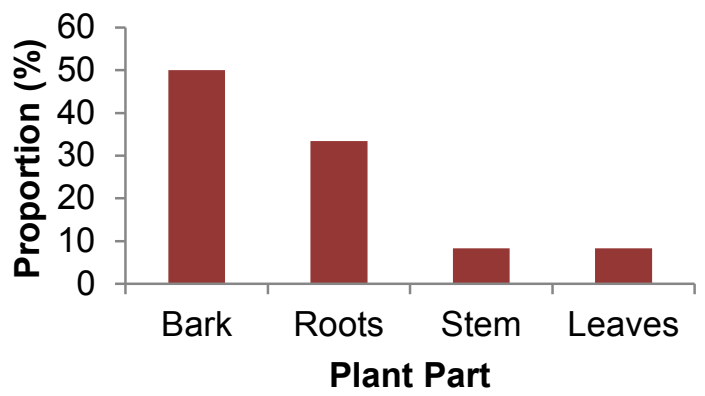

Figure 4. Proportion of ailments treated by the use of medicinal woody species in (A) Shorobe and (B) Xobe villages, northwest Botswana.

the lowest proportion of woody species and among use categories in Shorobe and Xobe Villages, respectively.

\section{Medicinal woody species}

Of the total number of families recorded in both study sites, 13 of them were represented by 23 woody species used for medicinal purposes (Table 2). Of these, 12 families represented by 16 species and six families represented by 11 species were encountered in Shorobe and Xobe, respectively, to treat 13 different human and animal diseases (Figure 4). Only four of these medicinal woody species were recorded from both study sites. Fabaceae had the highest number of woody species with medicinal values in Shorobe (four species) and Xobe (five species) followed by Capparaceae and Combretaceae, each with two species, in Shorobe and Xobe, respectively. The 23 woody species recorded as being useful for medicinal purposes represented 19 genera at both sites, of which 17 and eight species were found in Shorobe and Xobe, re- spectively (Table 2 ). The two study sites shared only four genera.

Of the total number of woody species recorded at each of the two study sites, the most commonly used plant parts were the roots, bark, leaves, and stems in both sites (Tables $1 \& 2$ ). A total of 16 (about $57 \%$ of identified species) and ten (about $37 \%$ of identified species) woody species were used in Shorobe and Xobe, respectively.

Treatments were administered orally, topically, and as steam baths. The oral route was the most frequently used route of administration in Shorobe $(78 \%)$ and Xobe (73\%). The roots and bark were the most popular plant parts used in the various herbal preparations in Shorobe (71\%) and Xobe (50\%), respectively (Figure 5$)$. The roots are favored because of their availability throughout the year and are also traditionally considered to be strong medicine. Decoctions, macerations, and concoctions, necessitating a mixture of several plants, are commonly used in treating 
Table 2. Reported medicinal uses of woody plants found in Shorobe and Xobe villages, northwest Botswana.

\begin{tabular}{|c|c|c|c|c|c|c|}
\hline \multirow[t]{2}{*}{ Species } & \multirow{2}{*}{ Medicinal uses } & \multirow{2}{*}{ 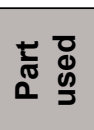 } & \multicolumn{2}{|c|}{ Mode of preparation } & \multicolumn{2}{|c|}{$\begin{array}{l}\text { Frequency } \\
\text { index }\end{array}$} \\
\hline & & & Shorobe & Xobe & Shorobe & Xobe \\
\hline Acacia erioloba E.Mey. & Cough & Bark & - & Bark boiled \& drunk & - & 8.6 \\
\hline Acacia hebeclada DC. & Cough & Root & Roots boiled \& drunk & Roots boiled \& drunk & 1.8 & 5.7 \\
\hline Acacia luederitzii Engl. & Toothache & Bark & - & $\begin{array}{l}\text { Bark boiled \& mouth } \\
\text { rinsed }\end{array}$ & - & 5.7 \\
\hline $\begin{array}{l}\text { Acacia mellifera } \\
\text { (M.Vahl) Benth. }\end{array}$ & Cough & Bark & - & Bark chewed & - & 22.9 \\
\hline $\begin{array}{l}\text { Albizia anthelmintica } \\
\text { Brongn. }\end{array}$ & Diarrhea & Root & $\begin{array}{l}\text { Roots warmed in } \\
\text { water \& drunk }\end{array}$ & - & 9.1 & - \\
\hline $\begin{array}{r}\text { Berchemia discolor } \\
\text { (Klotzsch) Hemsl. }\end{array}$ & $\begin{array}{l}\text { Toothache/ } \\
\text { Tooth problems }\end{array}$ & Bark & 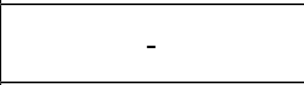 & Bark chewed & - & 2.9 \\
\hline \multirow{2}{*}{$\begin{array}{l}\text { Boscia albitrunca } \\
\text { (Burch.) Gilg \& Bene- } \\
\text { dict }\end{array}$} & Body rush & Root & Roots boiled \& bath & - & 16.4 & - \\
\hline & Makes tea & Root & - & $\begin{array}{l}\text { Bark dried, crushed } \\
\& \text { drunk as tea }\end{array}$ & - & 8.6 \\
\hline $\begin{array}{l}\text { Cadaba aphylla (Thunb.) } \\
\text { Wild }\end{array}$ & Male infertility & Root & Roots boiled \& drunk & 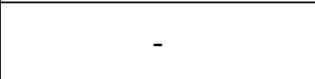 & 5.5 & - \\
\hline $\begin{array}{l}\text { Carissa bispinosa (L.) } \\
\text { Desf. ex Brenan }\end{array}$ & TB/Asthma & Root & Roots boiled \& drunk & - & 1.8 & - \\
\hline $\begin{array}{l}\text { Colophospermum mo- } \\
\text { pane (Benth.) Leonard }\end{array}$ & Diarrhea & Root & Roots boiled \& drunk & - & 24.5 & - \\
\hline $\begin{array}{l}\text { Combretum imberbe } \\
\text { Wawra }\end{array}$ & $\begin{array}{l}\text { Several ailments } \\
\text { (body pain) }\end{array}$ & Stem & - & $\begin{array}{l}\text { Burnt stem/ashes } \\
\text { applied to the body }\end{array}$ & - & 5.7 \\
\hline \multirow{2}{*}{$\begin{array}{l}\text { Croton megalobotrys } \\
\text { Müll.Arg. }\end{array}$} & Worms in fields & Leaf & $\begin{array}{l}\text { Crushed leaves \& } \\
\text { water poured in field }\end{array}$ & $\ldots$ & 3.6 & - \\
\hline & Animal wounds & $\begin{array}{l}\text { Leaf, } \\
\text { bark }\end{array}$ & ( & $\begin{array}{l}\text { Crushed leaves \& bark } \\
\text { applied to wounds }\end{array}$ & - & 5.7 \\
\hline $\begin{array}{l}\text { Erythrina lysistemon } \\
\text { Hutch. }\end{array}$ & Kidney problems & Root & Roots boiled \& drunk & 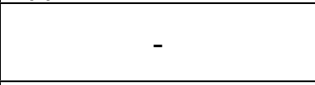 & 1.8 & - \\
\hline \multirow[b]{2}{*}{ Euclea undulata Thunb. } & Stomach cramps & Root & Roots boiled \& drunk & - & \multirow[b]{2}{*}{5.5} & - \\
\hline & Colorant & Root & $\begin{array}{l}\text { Crushed roots } \\
\text { boiled \& applied as } \\
\text { colorant }\end{array}$ & - & & - \\
\hline Grewia flava DC. & Cough & Root & Roots boiled \& drunk & - & 7.3 & - \\
\hline $\begin{array}{c}\text { Hyphaene petersiana } \\
\text { Klotzsch ex Mart. }\end{array}$ & Toothache & Root & $\begin{array}{l}\text { Roots boiled \& } \\
\text { mouth rinsed }\end{array}$ & - & 7.3 & - \\
\hline $\begin{array}{l}\text { Pavetta schumanniana } \\
\text { F.Hoffm. ex K.Schum. }\end{array}$ & Body cleansing & Root & Roots boiled \& drunk & Roots boiled \& drunk & 12.7 & 22.9 \\
\hline $\begin{array}{c}\text { Philenoptera nelsii } \\
\text { (Schinz) Schrire }\end{array}$ & Wounds & Bark & - & $\begin{array}{l}\text { Bark crushed \& ap- } \\
\text { plied to the wounds }\end{array}$ & - & 22.9 \\
\hline \multirow{2}{*}{$\begin{array}{l}\text { Sclerocarya birrea } \\
\text { (A.Rich.) Hochst. }\end{array}$} & Cough & Bark & Bark boiled \& drunk & - & \multirow[b]{2}{*}{3.6} & - \\
\hline & Toothache & Bark & $\begin{array}{l}\text { Bark boiled \& } \\
\text { mouth rinsed }\end{array}$ & - & & - \\
\hline $\begin{array}{l}\text { Securidaca longipedun- } \\
\text { culata Fresen. }\end{array}$ & $\begin{array}{l}\text { Different ailments } \\
\text { (body pains/kid- } \\
\text { ney problems) }\end{array}$ & Root & $\begin{array}{l}\text { Crushed roots } \\
\text { boiled \& drunk }\end{array}$ & - & 3.6 & - \\
\hline $\begin{array}{l}\text { Terminalia prunioides } \\
\text { M.A.Lawson }\end{array}$ & Diarrhea & Root & - & Roots boiled \& drunk & - & 11.4 \\
\hline $\begin{array}{l}\text { Terminalia sericea } \\
\text { Burch. ex DC. }\end{array}$ & Diarrhea & Bark & $\begin{array}{l}\text { Bark put in water for } \\
\text { some time \& drunk }\end{array}$ & - & 12.7 & - \\
\hline Ximenia americana L. & $\begin{array}{l}\text { Body rush/ } \\
\text { Wounds }\end{array}$ & $\begin{array}{l}\text { Root, } \\
\text { leaf }\end{array}$ & $\begin{array}{l}\text { Roots \& leaves } \\
\text { boiled and bath }\end{array}$ & - & 9.1 & - \\
\hline
\end{tabular}




\section{Neelo et al. - Ethnobotanical Survey of Woody Plants in Shorobe and Xobe Villages, Northwest Region of Botswana}

\section{A) Shorobe}

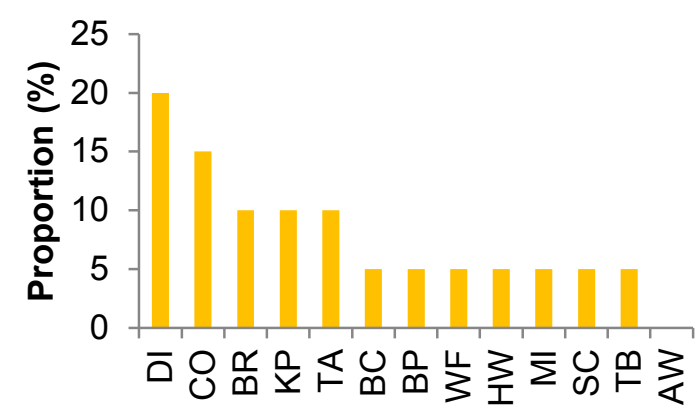

Ailment

\section{B) Xobe}

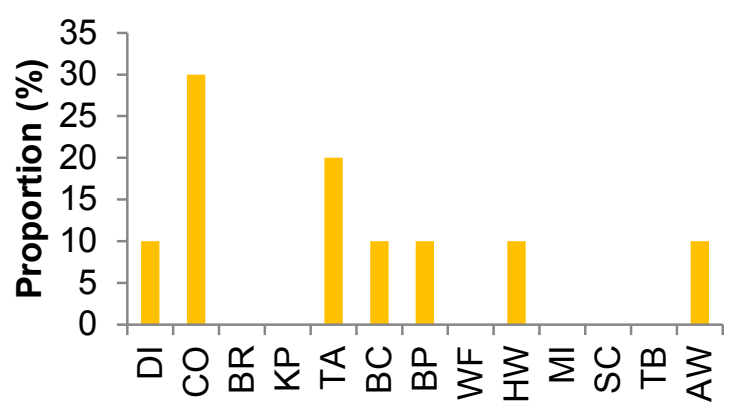

Ailment

Figure 5. Proportion of plant parts of woody species used for medicinal purposes in (A) Shorobe and (B) Xobe villages, northwest Botswana. $\mathrm{DI}=$ diarrhea, $\mathrm{CO}=\mathrm{BR}=$ body rush, $\mathrm{KP}=$ kidney problems, $\mathrm{TA}=$ toothache, $\mathrm{BC}=\mathrm{body}$ cleansing, $\mathrm{BP}=$ body pain, $\mathrm{HW}=$ human wounds, $\mathrm{MF}=$ male fertility, $\mathrm{SC}=$ stomach cramp, $\mathrm{TB}=$ tuberculosis, and $\mathrm{AW}$ $=$ animal wound.

some of the ailments, e.g., body cleansing, wounds, fractures, and other skin diseases which are treated topically.

Boscia albitrunca and Pavetta schumanniana F.Hoffm. ex K.Schum. from Shorobe and A. mellifera, P. nelsii, and T. prunioides from Xobe exhibited the highest frequency index, suggesting that they were mentioned more times by the respondents than the other species (Table 1). When all the use categories were considered, there were no differences in preferences between the two villages (Mann-Whitney test, $\mathrm{P}=0.4$ ). There were also no differences between the two villages in food $(P=0.4)$ and fuelwood $(P=0.7)$ categories. However, there were significant differences in the medicine $(P=0.001)$ and construction $(P=0.01)$ categories.

\section{Edible plants}

Some of the identified woody species recorded in Shorobe and Xobe are used as food sources by the local people. Nine of the 28 woody species (28\%) in Shorobe and nine of the 27 woody species (33.3\%) in Xobe provide edible parts (Tables 1). The most widely consumed parts of the plants from both villages are the fruits and bark while leaves are often used. For example, the fruits of $G$. damine are eaten as snacks and also used in the preparations of local beer known as khadi, which is a mixture of these fruits and a solution of sugar. The bark of $B$. albitrunca is dried and crushed into a powder and used as tea leaves. Some fruits, such as Hyphaene petersiana Klotzsch ex Mart., Grewia flava DC., and Diospyros mespiliformis Hochst. ex A.DC. are harvested and sold in the market, mostly by women and children to augment family income.

\section{Plants used for construction purposes}

Six (21\%) and eight (30\%) species out of the 28 and 27 woody species recorded in Shorobe and Xobe, respectively, are used for construction purposes (Table 1). The most common part used is the wood. The bark of $C$. mopane and leaves of $H$. pertasiana are also used as ropes to tie farm products and pieces of wood together for roofing. Plants such as Combretum hereroense Schinz, C. imberbe and Terminalia sericea Burch. ex DC. are also used as sources of timber for furniture and household items such as chairs, benches, stools, mortars, and pestles since their wood is very strong and durable.

\section{Plants used for fuelwood, fodder, and farm implements}

Several plants of these two villages still serve some other purposes that are crucial to human survival. Most plants are used as fuelwood for household energy generation (Table 1). This also serves as a means of generating income to fuelwood marketers. Combretum mossambicense (Klotzsch) Engl. and Ziziphus mucronata Willd. are mostly preferred by livestock as fodder. Combretum hereroense is also reputed as the best in the production of farm implements among the local communities, especially in Xobe Village (Table 1).

\section{Discussion}

Virtually all plants identified in the different families are useful in one way or another in the lives of the rural communities. Most species serve more than one function. For example, in addition to its main function as construction material, $C$. imberbe is widely used by the people in the 
treatment of body pains and wounds as well as making furniture. Some people use this plant also as a source of dye for their hair. Other species of the genus Combretum have been reported as important medicinal plants elsewhere. For example, Motlhanka \& Nthoiwa (2012) report that the people in the eastern Botswana use $C$. hereroense to treat headache and female infertility while the stem bark of $T$. sericea is used to treat diabetes. Combretum nigricans Lepr. ex Guill. \& Perr. is also reported to be effective in treating rheumatism (Amusa et al. 2010). Many studies have analyzed indigenous knowledge of plant use among different communities (e.g., Amusa et al. 2010, Babitseng \& Teketay 2013, Kala 2005, Motlhanka \& Makhabu 2011, Motlhanka \& Nthoiwa 2012, Neudeck et al. 2012, Rijal 2008).

The study reveals that medicinal plants account for a larger proportion of respondents' dependence on the woody vegetation around them. Although other traditional livelihood activities of agriculture (both arable and livestock), hunting, and gathering still play a significant role, their importance has been reduced, partly because the land they depend on (and its resources) is now used for other activities, such as tourism in the Delta and Ngamiland District as a whole. Therefore, the policies and regulations for tourism promotion and conservation have curtailed access to veld products (Kgathi et al. 2004). As noted by Amusa et al. (2010), use of traditional medicine is prevalent among rural communities of Africa. They have immense knowledge on ethnomedicine, although its use is rapidly diminishing, partly, due to lifestyle changes and exposure to Western ideologies.

Twelve human ailments from 28 woody species have been recorded in Shorobe, while seven ailments were recorded in Xobe out of 27 woody species. However, some species are overlapping in the treatment of the same ailment. This observation is similar to the reports of Amusa et al. (2010) on traditional knowledge systems of plants in Nigeria and Kala in India (Kala 2005). Generally, several factors are attributed to the dependency of local communities on traditional medicine. Traditional medicine, unlike modern medicine, is an integral component of many cultures, which has evolved for many generations, and it is considered effective in treating and managing certain cultural health problems (Sindiga 1994). It is also much cheaper than modern medicine.

In addition to the use of woody plants as medicines, other important uses were documented. Some of the species are also utilized for human food, construction and miscellaneous purposes such as fuelwood. Over-exploitation and commercial sale of some of the species will, in the future, threaten the long-term availability of a significant portion of such species, particularly $C$. mopane and $C$. imberbe, both of which are valued for firewood and con- struction purposes. However, these two species are still in abundance and have the highest density ranks and mean frequencies among studied species (Neelo et al. 2013). Nevertheless, an increasing number of reports have documented the over-harvesting of NTFPs and the negative effects on plant and animal populations in many nature reserves (Babitseng \& Teketay 2013, Bhatnagar 2002, Nuedeck et al. 2012, Shahabuddin \& Prasad 2004, Ticktin 2004). It is, therefore, imperative that the extent and impacts of exploitation of these species be studied to elucidate the need for enhanced conservation, and also to guarantee the livelihoods of the people. Further, the development of these groups of plants could serve as a basis for the implementation of a program aimed at encouraging local community involvement in the protection and management of the natural resources found in their area. This is more important given the fact that the surrounding vegetation in these villages is over-grazed (Neelo et al 2013) and seriously being encroached into by local communities and other settlers from different areas.

\section{Conclusions}

Many people in Shorobe and Xobe Villages still depend on plants growing around them for most of their needs. These plants play significant roles in the subsistence of the local communities. The key products harvested from the plants are medicines, edible fruits, firewood, timber, and poles. Of the 38 woody species identified in the study area, 23 are used to treat human ailments. Traditional uses of the studied plants ranged from treating inflammation or pain to respiratory problems, reproductive disorders, and infectious ailments. The most commonly treated ailment was pain. Across the studied plant families, the roots were the most commonly used plant parts. Due to relevance of native wild plants in improving health and providing services, such as fuelwood, human food, construction, and furniture, the promotion of conservation approaches on the woody vegetation resources is needed. The local communities have to be educated on propagation and conservation of woody plants, especially those mostly used for various important activities, such as fuelwood and medicines.

\section{Acknowledgments}

We are grateful to the International Development Research Centre (IDRC), through the Botswana Ecohealth Project, for providing financial support for this study. We are also thankful to the field technicians at Okavango Research Institute, community research assistants, the village leaders, and local people for their support during field work and data collection. We would also like to thank University of Botswana, Okavango Research Institute, for assistance granted to the project. 


\section{Neelo et al. - Ethnobotanical Survey of Woody Plants in Shorobe and Xobe Villages, Northwest Region of Botswana}

\section{References}

Abebe, D. \& E. Hagos. 1991. Plants as a primary source of drugs in the traditional health practices of Ethiopia. Pp. 101-113 in Plant Genetic Resources of Ethiopia. Edited by J.M.M. Engles, J.G. Hawkes \& M. Worede. Cambridge University Press, Cambridge, U.K.

Amusa, T.O., S.O. Jimoh, P. Aridanzi \& M. Haruna. 2010. Ethnobotany and conservation of plant resources of Kainji Lake National Park, Nigeria. Ethnobotany Research \& Applications 8:181-194.

Ayantunde, A.A., M. Briejer, P. Hiernaux, H.M.J. Udo \& R. Tabo. 2009. Uses of local plant species by agropastoralists in southwestern Niger. Ethnobotany Research \& Applications 7:53-66.

Babitseng, T.M. \& D. Teketay. 2013. Impact of Wine Tapping on the Population Structure and Regeneration of $\mathrm{Hy}$ phaene petersiana Klotzsch ex Mart. in Northern Botswana. Ethnobotany Research and Applications 11:09-27.

Balemie, K. \& F. Kebebew. 2006. Ethnobotanical study of wild edible plants in Derashe and Kucha Districts, South Ethiopia. Journal of Ethnobiology and Ethnomedicine 2(1):53-61. dx.doi.org/10.1186/1746-4269-2-53

Bhatnagar, P. 2002. Conservation and trade of medicinal herbs: A study of SafedMusli (Chlorophytum spp.) in Madhya Pradesh. Sustainable Forestry 7:11-14.

Botha, J., E.T.F. Witkowski \& C.M. Shackleton. 2004. Market profiles and trade in medicinal plants in the Lowveld, South Africa. Environmental Conservation 31:38-46. dx.doi.org/10.1017/S0376892904001067

Braedt, O. \& W. Standa-Gunda. 2000. Woodcraft markets in Zimbabwe. International Tree Crops Journal 10:36784. $\mathrm{dx}$.doi.org/10.1080/01435698.2000.9753021

Bussmann, R.W. 2006. Ethnobotany of the Samburu of Mt. Nyiru, South Turkana, Kenya. Journal of Ethnobiology and Ethnomedicine 2:35. dx.doi.org/10.1186/1746-4269$\underline{2-35}$

Campbell, B.M., S. Jeffery, W. Kozanayi, M. Luckert, M. Mutamba \& C. Zindi. 2002. Household Livelihoods in Semi-Arid Regions: Options and constraints. Center for International Forestry Research, Bogor, Indonesia.

Chidumayo, E.N. 1988. Estimating fuelwood production and yield in regrowth dry miombo woodland in Zambia. Forest Ecology Monograph 24:59-66. dx.doi. org/10.1016/0378-1127(88)90024-2
Chimbari, M.J., L. Magole, G. Wiles, K. Dikgola, N. Kurugundla, D. Teketay, B. Ngwenya, M.S. Nyepi, S. Motsumi, K. Ama, O. Thakadu \& O. Chombo. 2009. Application of the Ecohealth Approach to Understand Flood-Recession (Molapo) Farming in the Context of Hydro-Climate Variability and Hydro-climate Change in the Okavango Delta, Botswana. Okavango Research Institute, Maun, Botswana.

Chinemana, F., R.B. Drummond, S. Mavi \& I. De Zoysa. 1995. Indigenous plant remedies in Zimbabwe. Journal of Ethnopharmacology 14:159. dx.doi.org/10.1016/03788741(85)90084-4

CSO (Central Statistics Office). 2011. Botswana Population and Housing Census. Gaborone, Botswana.

DEA. 2008. Okavango Delta Management Plan. Department of Environmental Affairs (DEA), Gaborone, Botswana.

Dovie, D.B.K., E.T.F. Witkowski \& C.M. Shackleton. 2003. Direct-use value of smallholder crop production in semiarid rural South African village. Agricultural Systems 76:337-357. dx.doi.org/10.1016/S0308-521X(02)00124-5

Gerique, A. 2006. An Introduction to Ethnoecology and Ethnobotany: Theory and methods. University of Giessen, Giessen, Germany.

Hofstand, O. 1996. Woodland deforestation by charcoal supply to Dar es Salaam. Journal of Environmental Economics and Management 33:17-32. dx.doi.org/10.1006/ jeem.1996.0975

Holdings, C.P. \& G.C. Njuguna. 2001. Farm Sourced Timber: The restructuring of the timber industry in Kenya-opportunities and challenges. International Union of Forest Research Organizations, Vienna, Austria.

Hutchings, A. \& J. van Staden. 1994. Plants used for stress related ailments in traditional Zulu, Xhosa and Sotho medicine. Part I: Plants used for headaches. Journal of Ethnopharmacology 43:89-124. dx.doi.org/10.1016/03788741(94)90008-6

Kala, C.P. 2005. Indigenous uses, population density and conservation of threatened medicinal plants in protected areas of the Indian Himalayas. Conservation Biology 19:368-378. dx.doi.org/10.1111/j.15231739.2005.00602.x

Kgathi, D.L., H. Bendsen, P. Blaikie, J.E. Mbaiwa, B. Ngwenya \& J. Wilk. 2004. Rural Livelihoods, Indigenous Knowledge Systems, and Political Economy of Access to Natural Resources in the Okavango Delta, Botswana. Harry Oppenheimer Okavango Research Center, University of Botswana, Maun, Botswana. 
Kituyi, E. 2004. Towards sustainable production and use of charcoal in Kenya: Exploring the potential in life cycle management approach. Journal of Cleaner Production 12:1047-1057. dx.doi.org/10.1016/j.jclepro.2004.02.011

Krebs, C.J. 1989. Ecological Methodology. Harper Collins Publishers, New York, New York, U.S.A.

Leakey, R.R.B \& A.C. Newton. 1994. Tropical Trees: The potential for domestication and the rebuilding of forest resources. Her Majesty's Stationery Office, London, UK.

Legwaila, G.M., W. Mojeremane, M.E. Madisa, R.M. Mmolotsi \& M. Rampart. 2011. Potential of traditional food plants in rural household food security in Botswana. Journal of Horticulture and Forestry 3:171-177.

Letsela, T., E.T.F. Witkowski \& K. Balkwill. 2003. Plant resources used for subsistence in Tsehlanyane and Bokong in Lesotho. Economic Botany 57:619-639. dx.doi. org/10.1663/0013-0001(2003)057[0619:PRUFSI]2.0.

$\underline{\mathrm{CO}: 2}$

Luoga, E.J., E.T.F. Witkowski \& K. Balkwill. 2000. Economics of charcoal production in miombo woodlands of eastern Tanzania: Some hidden costs associated with commercialization of the resources. Ecological Economics 35:243-257. dx.doi.org/10.1016/S0921-8009(00)00196-8

Luoga, E.J., E.T.F. Witkowski \& K. Balkwill. 2002. Harvested and standing wood stocks in protected and communal miombo woodlands of eastern Tanzania. Forest Ecology and Management 16:15-30. dx.doi.org/10.1016/S03781127(01)00604-1

Madikizela, B., A.R. Ndhlala, J.F. Finnie, \& J. van Staden. 2012. Ethnopharmacological study of plants from Pondoland used against diarrhoea. Journal of Ethnopharmacology 141:61-71. dx.doi.org/10.1016/j.jep.2012.01.053

Mahwasane, S.T, L. Middleton \& N. Boaduo. 2013. An ethnobotanical survey of indigenous knowledge on medicinal plants used by the traditional healers of Lwamondo area, Limpopo Province, South Africa. South African Journal of Botany 88:69-75. dx.doi.org/10.1016/j. sajb.2013.05.004

Martin, G.J. 1995. Ethnobotany: A methods manual. Chapman and Hall, London, U.K. dx.doi.org/10.1007/9781-4615-2496-0

Motlhanka, D.M.T. \& S.W. Makhabu. 2011. Medicinal and edible wild fruit plants of Botswana as emerging new crop opportunities. Journal of Medicinal Plant Research 5:1836-1842.

Motlhanka, D.M. \& K.K. Nthoiwa. 2012. Phytochemical screening and antioxidant activity of Cardiospermum corindum L. faux persil from Botswana. Journal of Pharmaceutical Research and Opinion 2:184-187.

Neelo, J., D. Teketay, W. Masamba \& K. Kashe. 2013. Diversity, population structure and regeneration status of woody species in dry woodlands adjacent to molapo farms in northern Botswana. Open Journal of Forestry 3:138-151. dx.doi.org/10.4236/ojf.2013.34022

Neudeck, L., L. Avelino, P. Bareetseng, B.N. Ngwenya, D. Teketay \& M.R. Motsholapheko. 2012. The contribution of edible wild plants to food security, dietary diversity and income of households in Shorobe Village, northern Botswana. Ethnobotanical Research and Applications 10:449-462. http://journals.sfu.ca/era/index.php/era/article/view/752

Okoli, R.L., O. Aigbe, J.O. Ohaju-Obodo \& J.K. Mensah. 2007. Medicinal plants used for managing some common ailments among Esan People of Edo State, Nigeria. Pakistan Journal of Nutrition 6:490-496. dx.doi.org/10.3923/ pjn.2007.490.496

Paumgarten, F. 2005. The role of non-timber forest products as safety-nets: A review of evidence with a focus of South Africa. Geo Journal 64:189-197. dx.doi. org/10.1007/s10708-005-5647-x

Rijal, A. 2008. A quantitative assessment of indigenous plant uses among two Chepang communities in the Central Mid-hills of Nepal. Ethnobotany Research \& Applications 6:395-404. http://journals.sfu.ca/era/index.php/era/ article/view/248

SADC. 1993. Energy Statistics Year Book for 1991. Energy Sector, Luanda, Angola.

Scholes, R.J. \& S. Archer. 1997. Tree-grass interactions in savannas. Annual Review of Ecology and Systematics 28:517-544. dx.doi.org/10.1146/annurev.ecolsys.28.1.517

Setshogo, M.P. 2005. Preliminary Checklist of the Plants of Botswana. Southern African Botanical Diversity Network Report No. 37. Pretoria, South Africa, and Gaborone, Botswana.

Shackleton, C.M. 1996. Potential stimulation of local rural economies by harvesting secondary products: A case study from the Transvaal lowveld, South Africa. Ambio 25:33-38.

Shackleton, C.M., S.E. Shackleton, E. Buiten \& N. Bird. 2007. The importance of dry woodlands and forests in rural livelihoods and poverty alleviation in South Africa. Forest Policy and Economics 9:558-577. dx.doi.org/10.1016/i. forpol.2006.03.004 


\section{Neelo et al. - Ethnobotanical Survey of Woody Plants in Shorobe and Xobe Villages, Northwest Region of Botswana}

Shackleton, C.M., S.E. Shackleton, M. Ntshudu \& J. Ntzebeza. 2002. The role and value of savanna non-timber forest products to rural households in the Kat valley, South Africa. Journal of Tropical Forest Products 8:45-65.

Shahabuddin, G. \& S. Prasad. 2004. Assessing ecological sustainability of non-timber forest produce extraction: The Indian scenario. Conservation \& Society 2:235-250.

Sindiga, I. 1994. Indigenous (medical) knowledge of the Maasai. Indigenous Knowledge and Development Monitor 2:16-18.
Teketay, D., F. Senbeta, M. Maclachlan, M. Bekele \& P. Barklund. 2010. Edible Wild Plants in Ethiopia. Addis Ababa University Press, Addis Ababa, Ethiopia.

Ticktin, T. 2004. The ecological implications of harvesting non-timber forest products. Journal of Applied Ecology 41:11-21. dx.doi.org/10.1111/j.1365-2664.2004.00859.x

WWF/IUCN. 1994. Centres for plant diversity. A Guide and Strategy for their Conservation Volume 1. IUCN Publication unit, Cambridge, U.K. 
